\title{
Comparing the Stand Structure of a Secondary Mixed Forest with Three Broad-Leaved Forests in China's Greater Khingan Mountains
}

\author{
Huiwen Guan, Xibin Dong*, Tian Zhang, Zhiyong Wang, Jiafu Ruan \\ Key Laboratory of Sustainable Forest Management and Environmental Microorganism Engineering \\ of Heilongjiang Province, Northeast Forestry University, Harbin, China
}

Received: 18 October 2019

Accepted: 18 November 2019

\begin{abstract}
Stand structure is an important feature reflecting the status of forests. Here, four typical secondary forests in the Greater Khingan Mountains are examined. Five random plots were selected from each forest, and their tree size distributions and stand spatial structures were compared. The unary distributions of the diameters at breast height (DBH) and tree heights showed consistency, which indicated there was an over-abundance of small-diameter trees in these forests. The joint probability distribution showed that the number of small-diameter trees was significantly larger than that of large-diameter trees. Furthermore, according to the unary distribution of spatial structure characteristics, the stands mostly exhibited a clustered structure, and the competition in the stands was intense, which is not conducive to growth. One-way covariance analysis was used to test the similarities and differences in the spatial parameters of the four stands. There were no significant differences between them in terms of dominance or the uniform angle index. Only mingling was significantly different, where the mixed forest had a significant advantage $(p=0.05)$. The structure of these secondary stands is poor, so the formation of a stable forest ecosystem by natural succession is hampered.
\end{abstract}

Keywords: mixed and broad-leaved secondary forests, size distribution, spatial structure, unary and binary distribution

\section{Introduction}

There is a general consensus that mixed forests offer ecological and productivity advantages over singlespecies forests in most situations, e.g., higher habitat heterogeneity, high water-holding capacity, and greater diversity of species composition [1-4]. Meanwhile,

*e-mail: xibindong@nefu.edu.cn studies have explored ways to convert pure plantations into mixed forests [5]. Nevertheless, for secondary forests, including those resulting from deforestation and damage by natural hazards, few studies exist, and still fewer compare mixed stands with pure tree species stands.

Historically the Greater Khingan Mountains were rich in forest resources. However, due to severe damage from wildfires, especially in 1987, and continuous deforestation due to logging over many years, the forest status has been degraded, resulting in higher rates of 
soil erosion and lower quality of harvested timber [6]. The potential for human intervention to improve the stand status of forests is a source of controversy [7, 8]. Some researchers have found that forest planning provides many environmental benefits, and assists in making management decisions to improve the future state of forests. They have studied the effects of forest planning, and predicted how forests will change over time due to the effects of natural factors and human activities. Additionally, they applied advanced technology in forestry, producing land cover maps using satellite images and geographical information systems [9-14]. In China, the national government has issued a policy prohibiting commercial logging in designated natural forests, and scientists have made many efforts to improve the status of the nation's secondary forests [15].

An in-depth understanding of stand structure helps guide the formulation of effective, scientific forest management measures. Stand structure includes both spatial and non-spatial structure. Some scholars have studied the pattern of variation in non-spatial structural parameters [16-19] and consider it as indicative of the stability of forest stands, which can guide the direction of forest management to a certain extent [20, 21]. With the improvement of forest management and technology, the use of spatial structure to indicate stand status has been proposed. The spatial structure parameters of a stand can fully reflect various features of the spatial distribution of trees in the forest. These parameters also describe the relationships between trees, such as competitive interactions and spatial niches, which reflect the health, growth potential and stability of stands [22-24].

Diameter at breast height $(\mathrm{DBH})$ and tree height are two important aspects of non-spatial structure [25$30]$. Because the values of these two variables are easy to accurately obtain in small-scale regions, they are commonly used as key variables for understanding stand volume and forest growth and for evaluation of forest status. Liang, P. et al. [31] found that forest height was important in shaping the altitudinal change in radial growth response to climate change, which indicates that forest height can reflect the status of the stand. Many scholars have attempted to model the height-diameter relationship [29, 30, 32-37] and then estimate stand volume by fitting a related model. Such models can aid in formulating forest management measures [36, 38]. The description and explanation of spatial structure and the relationships between single trees have become the focus of forest structure research $[8,22]$ and are receiving increased attention. Rather than a description that focuses on analyzing individual forests as statistical units through statistical techniques [39-42], a quantitative analysis based on the relationship between neighbouring trees can enable managers to better understand the structure of a forest's microenvironment and make quantitative adjustments to the forest structure accordingly [8]. For example, mingling indicates the degree of isolation of different tree species in a stand. Hui G.Y. et al. [43] proposed the concept of dominance, which clearly describes tree size in a forest. Hui G.Y. [44] first proposed the concept of the uniform angle index, which describes the spatial distribution of forest trees. The uniform angle index, mingling and dominance are parameters that collectively quantify and describe the spatial structure of a forest and can provide spatial information such as tree distribution, mixing of species and tree size in a forest [45-47].

Analysis of the current forest structure can provide important information to assist in developing forest management strategies [48]. In this paper, the structures of a mixed forest and three pure forests in the Greater Khingan Mountains were analysed according to tree size distribution characteristics and stand spatial structure [20,49] in order to comprehensively reveal the structural characteristics of the four types of stands. The tree size distribution and spatial structural characteristics of the forests were compared and analysed. The distributions of $\mathrm{DBH}$ and tree height are discussed, and the growth status of the stands are measured to reflect their competition, differentiation and natural sparseness. Also, the binary distribution of $\mathrm{DBH}$ and tree height is used to describe the joint probability between tree height and $\mathrm{DBH}$ in order to reveal the internal structural relationship between the two factors. This was done in order to: a) more fully understand the stand structure; b) accurately predict changes in the diameter classes and accumulation of the trees; c) understand the spatial information of the forest stands based on the unary distribution of spatial structural parameters (forest distribution pattern, mixed state and size) [50]; d) compare the differences in spatial structural parameters among various types of natural forests by covariance analysis; e) reveal intrinsic structural relationships through the joint frequency distribution between two of the three structural parameters; and f) provide additional abundance and microscopic spatial structural information for specific forests. We try to quantify the characteristics of stand structure of secondary forests in order to: (1) reflect the current status of various kinds of secondary forest (to help determine if it is possible for these stands to regenerate naturally, and to provide reference to further management and manual intervention); and (2) to compare the stand structure of a mixed forest with broad-leafed forests to determine if a mixed forest offers a stand structure advantage for regenerating a secondary forest.

\section{Martials and Methods}

\section{Study Site}

The study area is located in the Yuejin Forest Farm and Cuifeng Forest Farm of the Jiagedaqi Forestry Bureau in the Greater Khingan Mountains (Fig. 1). 


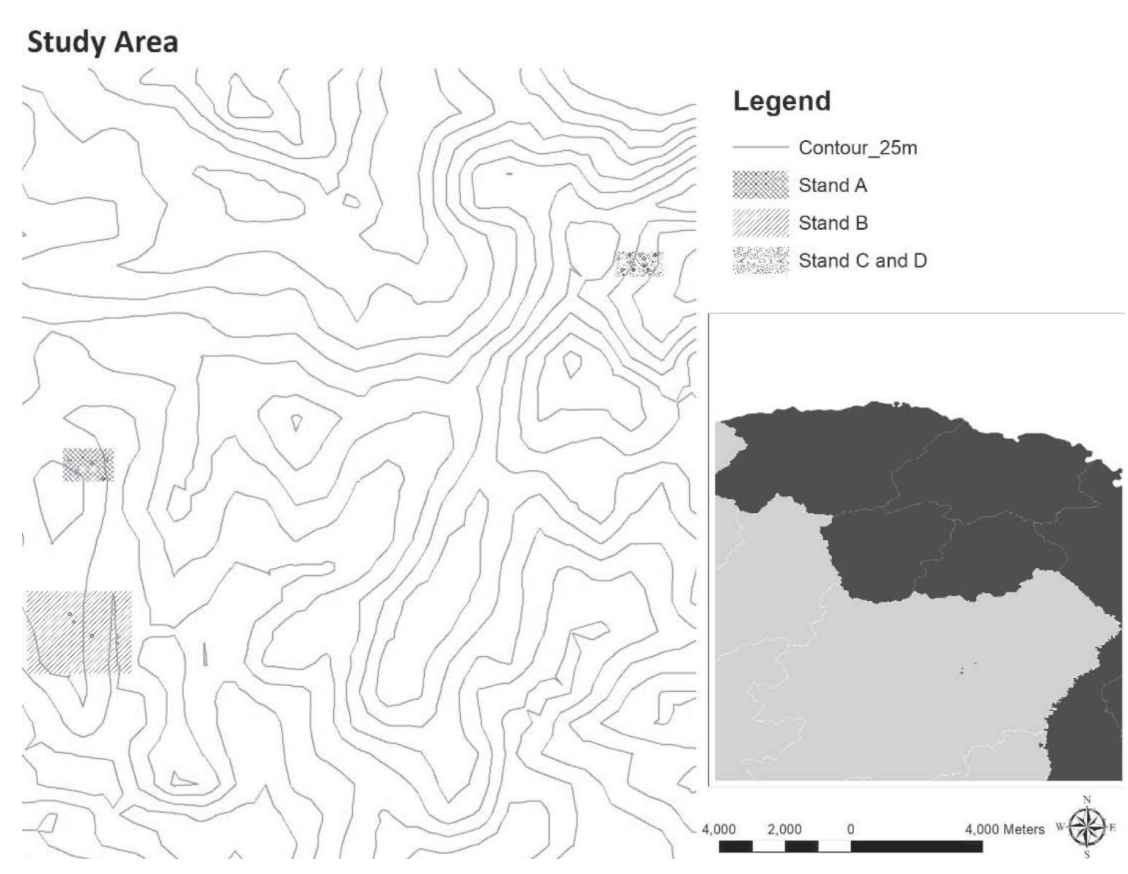

Fig. 1. Map of study area. The left is the location of the forest farm and dots mean the sample plots. Meanwhile, the red line is the contour line of $25 \mathrm{~m}$. The right is the location of the forest farm belonging to Nei Mongol Province.

The topography includes low hills, with an elevation of around 430 to $520 \mathrm{~m}$ and a slope of no more than $10^{\circ}$. Most of the forest soil is dark brown, with a thickness of about 10 to $25 \mathrm{~cm}$. The annual frost-free period is 80 to 110 days, and the average annual precipitation is above $500 \mathrm{~mm}$. The area has a cold, temperate, continental monsoon climate. Winters are long and cold, and summers are very short; however, sunshine duration is very long. The temperature difference between day and night is very large, and the annual average temperature is only $-1.2^{\circ} \mathrm{C}$ [15]. Mixed coniferous and broad-leaved, low-quality forests were selected from the 51 forest classes at Yuejin Forest Farm (124ำ $\left.14^{\prime} 44.4^{\prime \prime}-124^{\circ} 15^{\prime} 35.5^{\prime \prime} \mathrm{E}, 50^{\circ} 30^{\prime} 45.3^{\prime \prime}-50^{\circ} 31^{\prime} 17.4^{\prime \prime} \mathrm{N}\right)$. Three pure-stand forests were selected, including low-quality Populus davidiana forests from the 54 forest classes at Yuejin Forest Farm (124'14'9.5"$\left.124^{\circ} 15^{\prime} 54.5^{\prime \prime} \mathrm{E}, \quad 50^{\circ} 27^{\prime} 37.85^{\prime \prime}-50^{\circ} 28^{\prime} 56.5^{\prime \prime} \mathrm{N}\right)$ and

Table 1. Survey of forest lands.

\begin{tabular}{|c|c|c|c|c|}
\hline Stand types & A & $\mathrm{B}$ & $\mathrm{C}$ & $\mathrm{D}$ \\
\hline Item & Mixed forest & $\begin{array}{c}\text { Populus davidiana } \\
\text { forest }\end{array}$ & $\begin{array}{l}\text { Quercus mongolica } \\
\text { forest }\end{array}$ & $\begin{array}{c}\text { Betula platyphylla } \\
\text { forest }\end{array}$ \\
\hline Slope aspect & North & West & Southeast & Northeast \\
\hline Slope position & Upper & Middle & Middle & Middle \\
\hline Gradient $\left(^{\circ}\right)$ & 4 & 6 & 8 & 7 \\
\hline Soil depth (cm) & 22 & 20 & 22 & 22 \\
\hline Dominant species in arbour layer & $\begin{array}{c}\text { Larix gmelinii } \\
\text { Betula platyphylla } \\
\text { Quercus mongolica }\end{array}$ & Populus davidiana & Quercus mongolica & Betula platyphylla \\
\hline Canopy coverage in arbour layer & 0.3 & 0.4 & 0.4 & 0.3 \\
\hline Average diameter in arbour layer $(\mathrm{cm})$ & 8.6 & 7.8 & 8.9 & 11 \\
\hline Average tree height in arbour layer (m) & 8 & 5.2 & 7.4 & 9 \\
\hline Shrub species & Lespedeza bicolor & Corylus chinensis & Lespedeza bicolor & Salix wangiana \\
\hline Shrub coverage $(\%)$ & 17 & 15 & 15 & 12 \\
\hline Herb species & Carex callitrichos & Convallaria majalis & Atractylodes lancea & Cyperus rotundus \\
\hline Herb coverage $(\%)$ & 29 & 21 & 30 & 27 \\
\hline
\end{tabular}


Table 2. Definitions and values of each spatial structure index.

\begin{tabular}{|c|c|c|c|c|c|c|}
\hline \multirow{2}{*}{ Index } & Formula & \multicolumn{4}{|c|}{ Value } \\
\cline { 3 - 6 } & $W_{i}=\frac{1}{4} \sum_{j=1}^{4} z_{i j}$ & $\begin{array}{c}\text { Absolutely } \\
\text { uniform }\end{array}$ & Uniform & Random & Nonuniform & Clumped \\
\hline $\mathrm{U}$ & $W_{i}=\frac{1}{4} \sum_{j=1}^{4} k_{i j}$ & Predominant & Subdominant & Moderate & Inferior & Extremely inferior \\
\hline $\mathrm{M}$ & $W_{i}=\frac{1}{4} \sum_{j=1}^{4} v_{i j}$ & Not mixed & Weakly mixed & Medium mixed & Strongly mixed & Extremely \\
strongly mixed
\end{tabular}

Quercus mongolica and Betula platyphylla forests from among the 174 forest classes at Cuifeng Forest Farm $\left(124^{\circ} 23^{\prime} 47.8^{\prime \prime}-124^{\circ} 24^{\prime} \quad 35.1^{\prime \prime} \mathrm{E}, \quad 50^{\circ} 34^{\prime}\right.$ 9.17"$\left.50^{\circ} 34^{\prime} 32.0^{\prime \prime} \mathrm{N}\right)$. Site conditions of the four types of lowquality forests at the time when the study area was set up (2009) are shown in Table 1.

\section{Sample Collection}

Five $50 \times 50 \mathrm{~m}$ typical plots were randomly established in each of the four types of natural forest stands, so a total of 20 plots (Fig. 1) were surveyed and sampled (in August 2018). In each plot, we investigated each tree with a DBH greater than $3 \mathrm{~cm}$. Data collected during the survey included the species name, DBH, crown width, tree height and location coordinates. In each plot, the indexes of spatial structure (uniform angle index, mingling and dominance) and stand factors (diameter at breast height, tree height and crown width) of the stands were calculated.

\section{Data Analysis}

The DBH distribution and tree height distribution of each forest were established based on the number of plants per hectare at each plot. The 'moments'
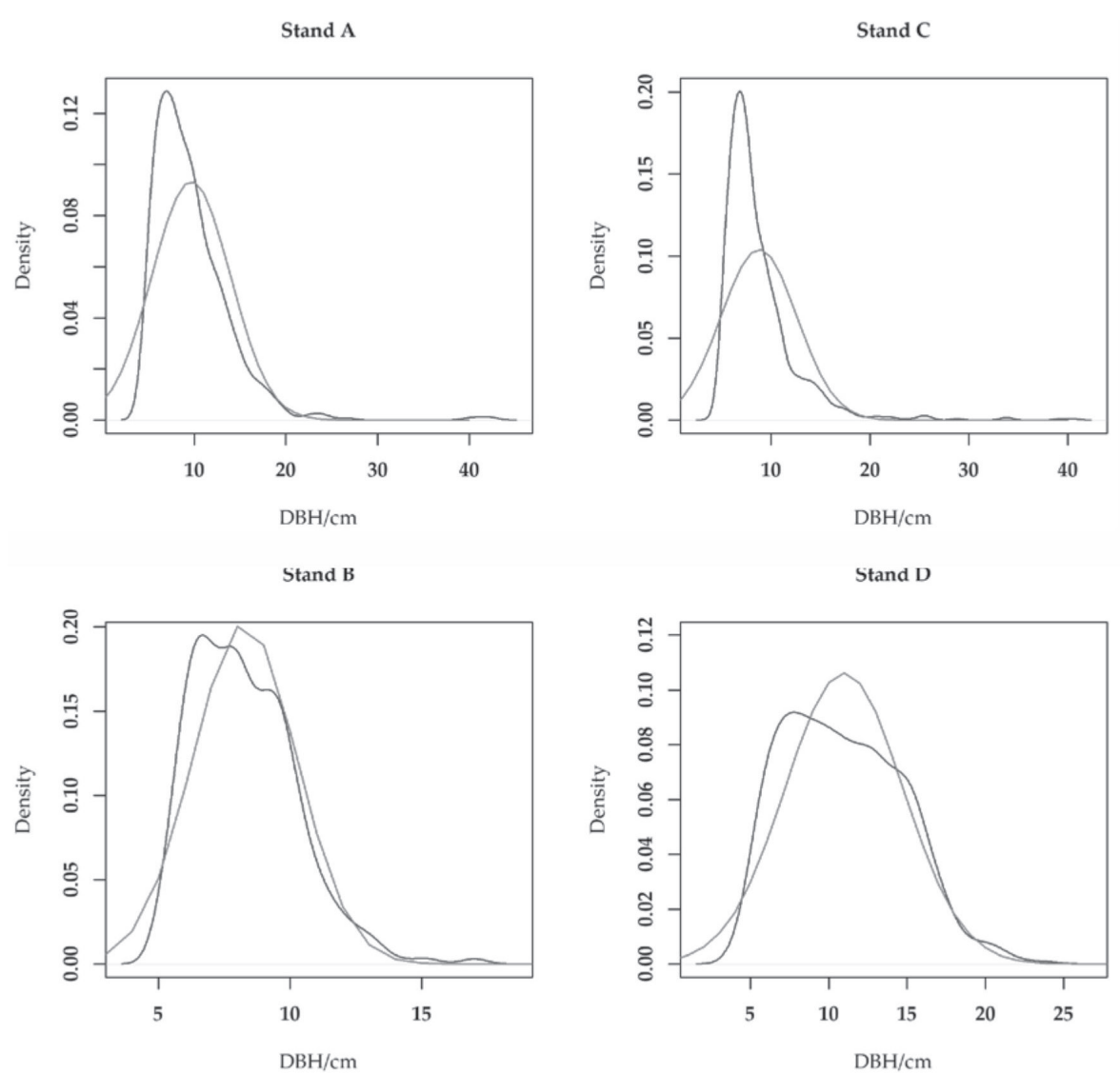

Fig. 2. Distributions of tree DBH in stands of different types of forests. The blue line in the figure indicates the actual distribution of the $\mathrm{DBH}$ of the forest, and the red line indicates the normal distribution curve based on the mean and standard deviation of the DBH. 
package in R statistical software was used to analyse the parameters of the unitary distributions of DBH and tree height in each stand, including the mean, skewness and kurtosis. The Mclust function performs bivariate joint density estimation and analysis of corresponding parameters, and the plot function creates a threedimensional graph of the bivariate results [51]. In this study, the forest size and tree height in the five plots of each type of natural forest were combined, and the tree size distribution characteristics of different types of forests were analysed using the above methods.

The uniform angle index $(W)$, mingling $(M)$ and dominance $(U)$ of each stand were calculated using the information shown in Table 2 [8]. To avoid edge effects, a buffer of $1 \mathrm{~m}$ was set. The relative frequencies of tree species with each value were counted, and the distribution frequency, that is, the unary distribution of spatial structural parameters, was obtained. The three structural parameters were combined to form the following three pairs: mingling $(M)$-dominance $(U)$, mingling $(M)$-uniform angle index $(W)$, and dominance $(U)$-uniform angle index $(W)$. Next, the relative frequency of the number of trees in each combination was taken as the ordinate, and the different values were combined and taken as the abscissa. A binary distribution of the spatial structural parameters was obtained. Using Excel 2013, the spatial structural diversity of mixed and broad-leafed forests was mapped and analysed.

The $z_{i j}$ expresses whether the angle $(\alpha)$ of an adjacent tree compared to the reference tree is less than the standard angle $\alpha_{0}\left(\alpha_{0}=72^{\circ}\right)$, if $\alpha<\alpha_{0}, z_{i j}=1$. Otherwise, $z_{i j}=0$. The average $W$ reflects the overall level of the forest relative to three distributions: random, clumped, and uniform, which occur between $(0.475,0.517)$, above 0.517 and below 0.475 , respectively. When the nearest neighbour is larger than the reference tree, $k_{i j}=1$. Otherwise, $z_{i j}=0$. When the species of the nearest neighbour is not the same as the reference tree, $v_{i j}=1$. Otherwise, $v_{i j}=0$.

\section{Results and Discussion}

\section{Forest Size Distribution Characteristics}

As shown in Fig. 2, the DBH of forest stands A and $\mathrm{C}$ have a single-peak unary distribution, while stands $\mathrm{B}$ and $\mathrm{D}$ have a distinct multimodal distribution. To better quantify the $\mathrm{DBH}$, the relevant parameters were calculated in R. The results are shown in Table 3. The average DBH of stands A to D are $9.66 \mathrm{~cm}$, $8.28 \mathrm{~cm}, 8.79 \mathrm{~cm}$ and $10.79 \mathrm{~cm}$ respectively, i.e., not very thick, which is consistent with the characteristics
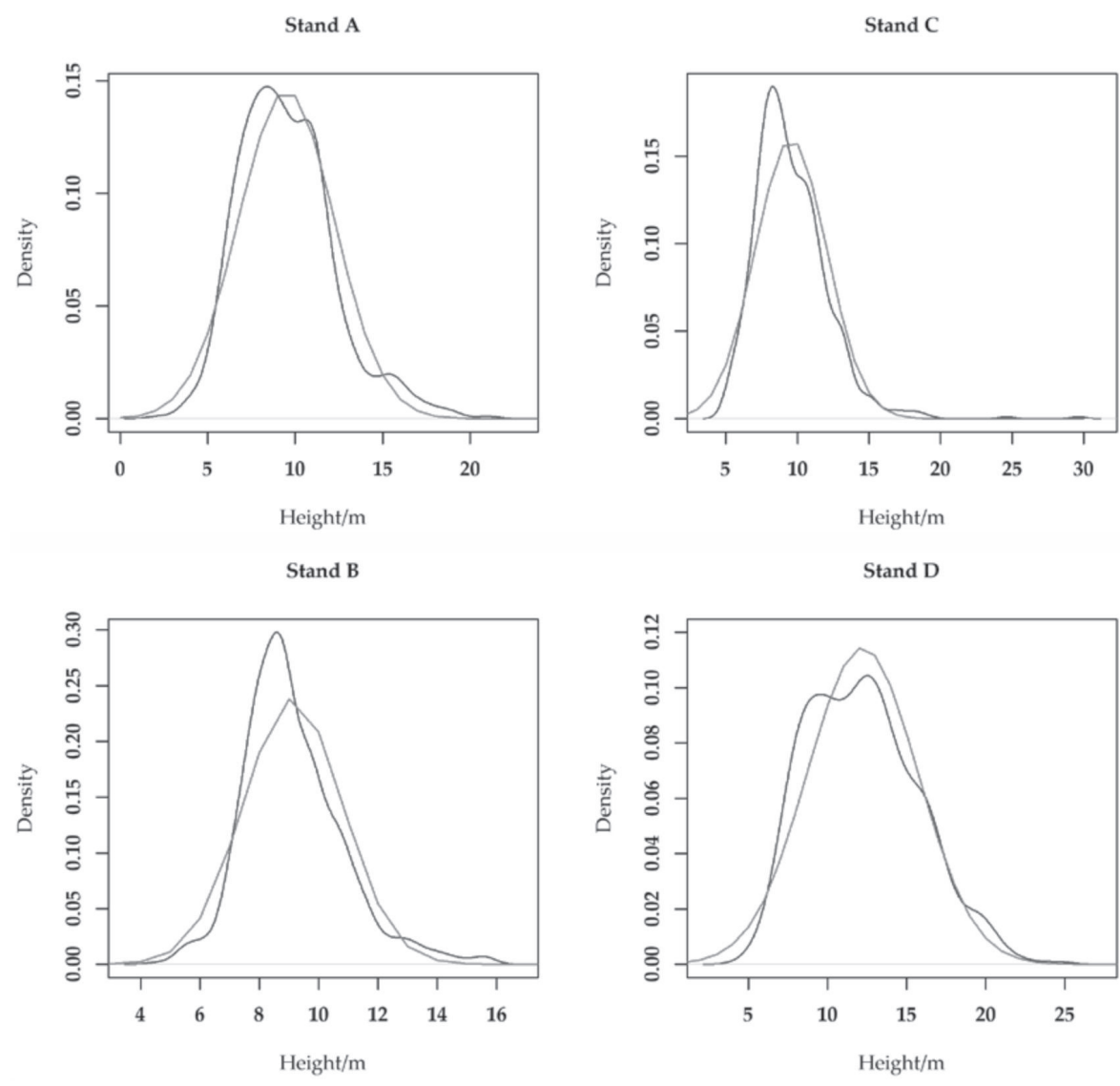

Fig. 3. Distributions of tree height in stands of different types of forests. The blue line in the figure indicates the actual distribution of the tree heights of the forest, and the red line indicates the normal distribution curve based on the mean and standard deviation of tree height. 
Table 3. Distribution parameters of tree DBH.

\begin{tabular}{|c|c|c|c|c|c|c|}
\hline Stand types & Skewness & Kurtosis & Mean / cm & Variance & $\begin{array}{c}\text { Variable coefficient } \\
(\mathrm{Cv}) / \%\end{array}$ & $\begin{array}{c}\text { Standard deviation } \\
(\mathrm{Sd}) / \mathrm{cm}\end{array}$ \\
\hline A & 2.78 & 18.19 & 9.66 & 18.21 & 44.19 & 4.27 \\
\hline B & 0.88 & 4.23 & 8.28 & 3.88 & 23.82 & 1.97 \\
\hline C & 3.31 & 20.68 & 8.79 & 14.64 & 43.53 & 3.83 \\
\hline D & 0.41 & 2.55 & 10.97 & 14.09 & 34.20 & 3.75 \\
\hline
\end{tabular}

of low-quality forests. The corresponding coefficients of variation are $44.19,23.83,43.53$ and 34.20 , respectively. The difference in DBH between trees is greatest in stand A and smallest in stand B, which is also reflected in the variance and standard deviation. The skewness is $2.78,0.88,3.31$, and 0.41 , all of which are positive values, indicating that the curves are biased to the left. The peaks of stands A, B and C are at 18.19, 4.23 and 20.68 , respectively, and their values are greater than 3 , indicating that the curves exhibit pointed kurtosis ("spike" curves). The stand D peak is at 2.55 , which is less than 3 , indicating that the distribution exhibits flat kurtosis (a "flat-top" curve). The DBH of the four types of natural forests revealed more trees with small diameters.

As shown in Fig. 3, the tree height of stands B and $\mathrm{C}$ have a single-peak unary distribution, while those of stands $\mathrm{A}$ and $\mathrm{D}$ have a distinct multimodal distribution. The relevant parameters are shown in Table 4. The average tree heights of the four types of stands are $9.50 \mathrm{~m}, 9.13 \mathrm{~m}, 9.55 \mathrm{~m}$ and $12.22 \mathrm{~m}$ respectively. The corresponding coefficients of variation are 22.80, 18.31, 26.18 and 28.52. The difference in tree height between trees in stand $\mathrm{A}$ is greatest, and that in stand $\mathrm{B}$ is the smallest (consistent with the DBH), which is also reflected in the variance and standard deviation. The skewness is $0.77,0.88,1.56$ and 0.41 - all of which are positive values, indicating that the curves are biased to the left. Furthermore, the values are so small that the curve is similar to a normal distribution. The peaks of stands A, B and C are at 4.05, 4.59, and 10.00 , respectively, and their values are greater than 3 , indicating that the curves exhibit pointed kurtosis (spike curves). However, the stand D peak is at 2.75 , which is less than 3 , indicating that the distribution exhibits flat kurtosis (a flat-top curve).
As shown in Fig. 4, the joint distribution of DBH and tree height in stand A exhibits a single peak. The number of small-diameter trees is significantly more than those of large-diameter. The stand diameter and tree height of stand B combine to show a two-peak distribution. However, the number of small diameter trees is still greater than those with large diameters. The distribution of DBH and tree height in stand $\mathrm{C}$ has a single peak, and the stand is dominated by smalldiameter trees. The stand diameter and tree height jointly show a two-peak distribution in stand $\mathrm{D}$, and the DBH is mainly $<15 \mathrm{~cm}$.

The DBH of both mixed and pure forests is small, i.e., left-biased compared with the normal distribution, indicating that the small size of trees in the current forest will take a long time to become mature and the stands are not stable, which is also indicted by the distribution of tree height. Moreover, the distributions of tree height and DBH are consistent, although some other researchers found a nonlinear relationship between them $[25,29,52]$. The differences among the five plots in each forest were consistent, both in tree height and DBH. The five plots in stand B were all quite different, while the forms of the distribution curves of the other stands were generally the same. However, the curves of tree height for the stands are more similar to a normal distribution, reflecting how height develops before diameter in the tree species we studied. This is similar to the findings of Xiang, W. et. al [53], which showed that when $\mathrm{DBH}<10 \mathrm{~cm}$, the value of mean height is bigger than DBH in the secondary forest. However, we did not explore the specific relationship between DBH and tree height in detail. Therefore, we can only use the results obtained thus far to analyse the tree size distribution of the four forests. The DBH and height of the trees in the birch forest were the greatest among the four forests. By

Table 4. Distribution parameters of tree height.

\begin{tabular}{|c|c|c|c|c|c|c|}
\hline Stand types & Skewness & Kurtosis & Mean $/ \mathrm{m}$ & Variance & $\begin{array}{c}\text { Variable coefficient } \\
(\mathrm{Cv}) / \%\end{array}$ & $\begin{array}{c}\text { Standard deviation } \\
(\mathrm{Sd}) / \mathrm{m}\end{array}$ \\
\hline A & 0.77 & 4.05 & 9.50 & 7.48 & 28.80 & 2.74 \\
\hline B & 0.88 & 4.59 & 9.13 & 2.79 & 18.31 & 1.67 \\
\hline C & 1.56 & 10.00 & 9.55 & 6.25 & 26.18 & 2.50 \\
\hline D & 0.44 & 2.75 & 12.22 & 12.14 & 28.52 & 3.48 \\
\hline
\end{tabular}


Stand A

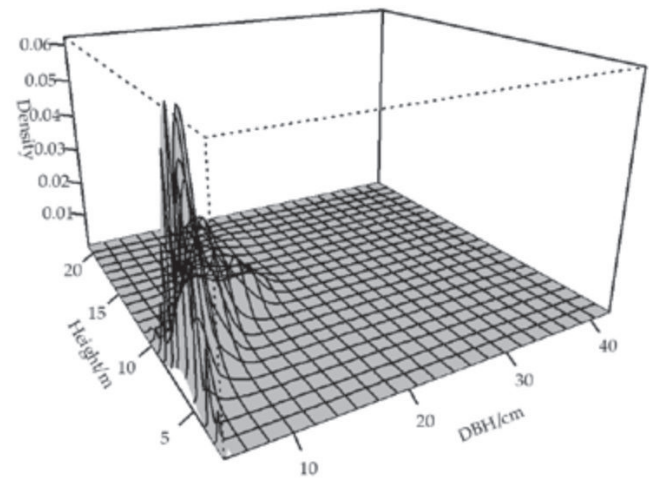

Stand B

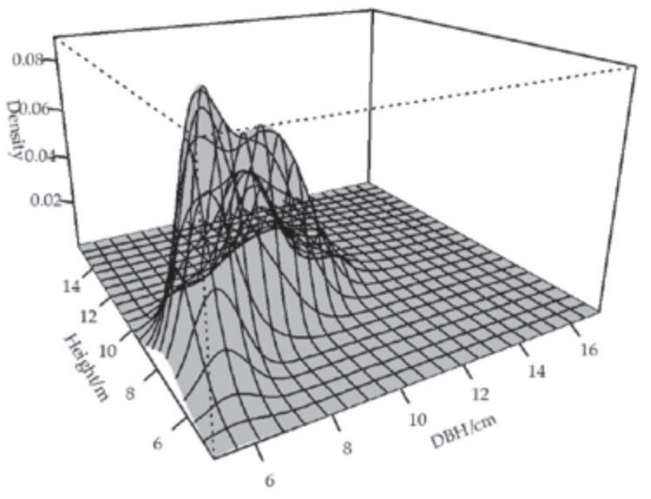

Stand C

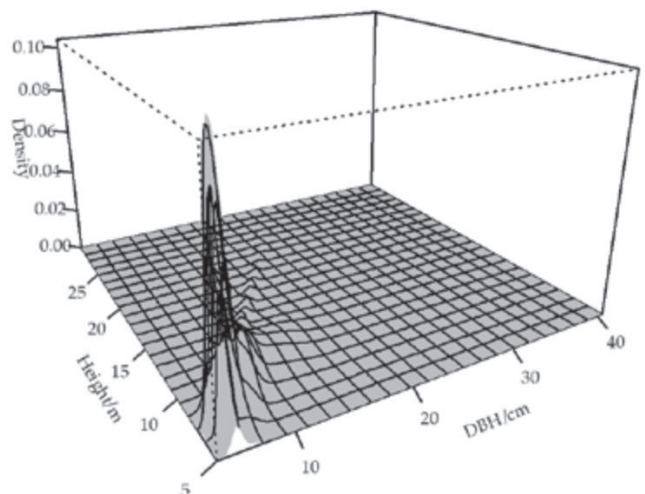

Stand D

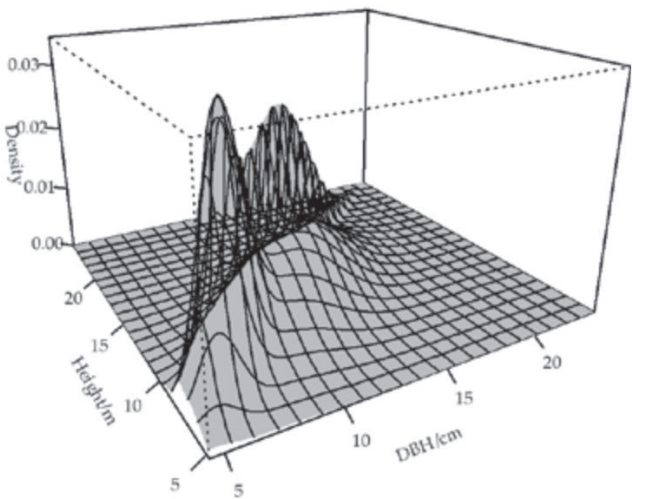

Fig. 4. Graphic representation of two bivariate mixtures involving DBH and height for the four stand types.

analysing the joint probability distribution of $\mathrm{DBH}$ and tree height in the stands, we can conclude the following: although stands $\mathrm{B}$ and $\mathrm{D}$ have a two-peak distribution while stands $\mathrm{A}$ and $\mathrm{C}$ have a single-peak distribution, the number of trees with a small or medium diameter in all four stands is significantly greater than that of trees with a large diameter. The trees in the four forest types are small and need more time to mature.

\section{Stand Spatial Structure Characteristics \\ Unary Distribution of Spatial Structure}

First, when the average value of the uniform angle index is between $[0.475,0.517]$, it exhibits a random distribution; when it is $>0.517$, it exhibits an aggregated distribution; and when it is $<0.475$, it exhibits

Table 5. Average uniform angle index of stand under different types of forest.

\begin{tabular}{|c|c|c|c|c|c|c|c|}
\hline Sample & $\begin{array}{c}\text { Uniform } \\
\text { angle index }\end{array}$ & Sample & $\begin{array}{c}\text { Uniform } \\
\text { angle index }\end{array}$ & Sample & $\begin{array}{c}\text { Uniform } \\
\text { angle index }\end{array}$ & Sample & $\begin{array}{c}\text { Uniform } \\
\text { angle index }\end{array}$ \\
\hline A1 & 0.750 & B1 & 0.617 & C1 & 0.596 & D1 & 0.598 \\
\hline A2 & 0.531 & B2 & 0.613 & C2 & 0.518 & D2 & 0.560 \\
\hline A3 & 0.508 & B3 & 0.587 & C3 & 0.576 & D3 & 0.605 \\
\hline A4 & 0.564 & B4 & 0.529 & C4 & 0.581 & D4 & 0.610 \\
\hline A5 & 0.597 & B5 & 0.556 & C5 & 0.523 & D5 & 0.580 \\
\hline Mean & 0.590 & Mean & 0.580 & Mean & 0.559 & Mean & 0.591 \\
\hline Standard & 0.085 & Standard & 0.034 & Standard & 0.032 & Standard & 0.018 \\
\hline
\end{tabular}



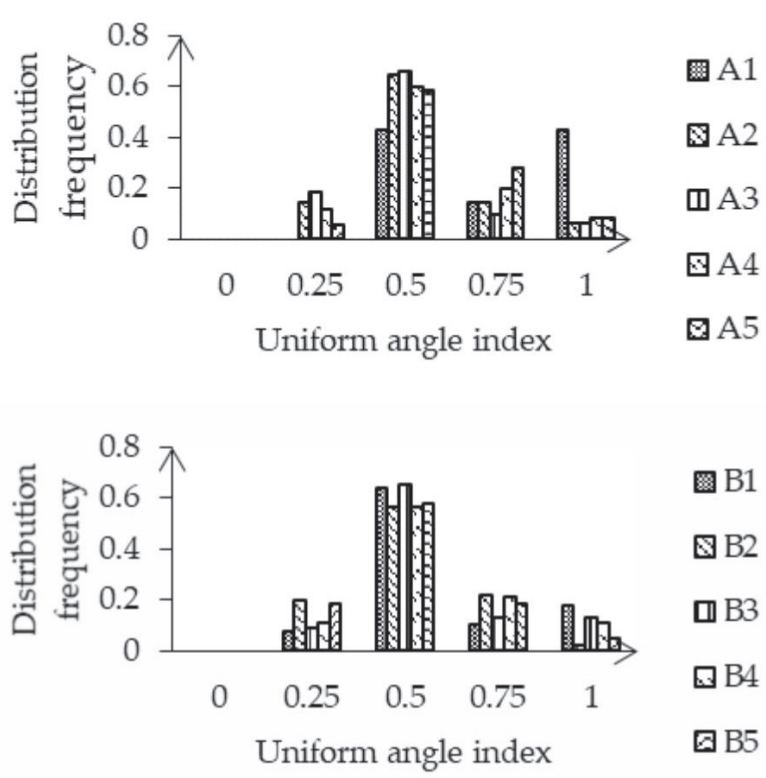
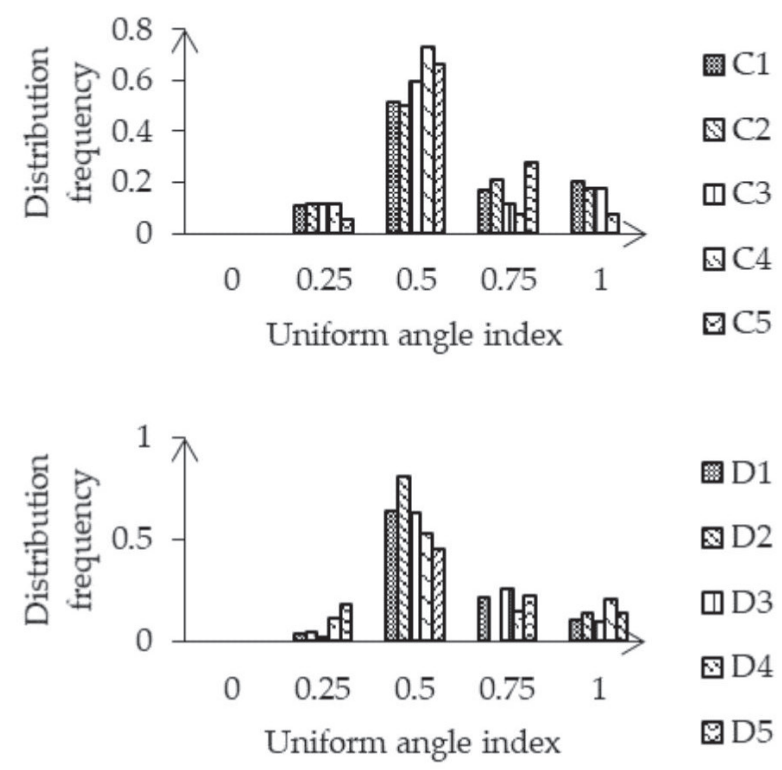

Fig. 5. Distribution frequency of the uniform angle index of stands in different types of forests.

a uniform distribution [30]. As shown in Table 5, except for the A3 plot (whose average value for the uniform angle index is 0.508 , indicating a random distribution), the average value of the indexes is greater than 0.517 , indicating an aggregated distribution and a clustered structure. Based on the relative frequencies of different values of the uniform angle index, the frequency distributions of the four forest types are similar. The 0.5 frequency is the highest, and there are no sample plots with a value of 0 . Although each set of 5 experimental plots was selected from within the same type of stand, the uniform angle index distribution within each plot is variable. For example, the frequency (1) of the A1 plot is significantly high. The average uniform angle indexes of the four forest types are $0.590,0.580,0.559$, and 0.591 , which indicates a clustered structure (Fig. 5). The differences between the five experimental plots in stand A (mixed forest) are the largest, and the standard deviation is 0.085 .

As shown in Table 6, the mingling in the five plots in each stand are as follows: stand $\mathrm{A}-0.500$,
$0.505,0.625,0.443,0.410$, with an average value of $0.497 \pm 0.073$; stand B $-0.348,0.125,0.090,0.500,0.403$, with an average value of $0.293 \pm 0.160$; stand $\mathrm{C}-0.513$, $0.335,0.130,0.319,0.176$, with an average value of $0.295 \pm 0.135$; and stand D $-0.223,0.393,0.140,0.074,0$, with an average value of $0.165 \pm 0.135$. The differences in the mingling in stand A (a coniferous and broad-leaved mixed forest) are small, and the degrees of mingling are above 0.4. Stands B, C, and D are intended to represent pure forests, but this is almost impossible to achieve under natural conditions. Based on the results, there is a large difference in mingling among the five experimental plots randomly selected within each stand. Some samples are close to 0 , while others are as high as 0.5 , which reflects the complexity of the tree species composition in the test area. In general, the mingling in stand D is the lowest. As shown in Fig. 6, the distribution frequencies are generally the same for the different values of mingling, i.e., within the range of $0-1$, and there are no obvious dominant intervals.

In terms of the spatial structural parameters of the stand, the results showed that except for the A3 plot

Table 6. Average mingling in stands of different types of forests.

\begin{tabular}{|c|c|c|c|c|c|c|c|}
\hline Sample & Mingling & Sample & Mingling & Sample & Uniform angle index & Sample & Mingling \\
\hline A1 & 0.500 & B1 & 0.348 & C1 & 0.513 & D1 & 0.223 \\
\hline A2 & 0.505 & B2 & 0.125 & C2 & 0.335 & D2 & 0.393 \\
\hline A3 & 0.625 & B3 & 0.090 & C3 & 0.130 & D3 & 0.140 \\
\hline A4 & 0.443 & B4 & 0.500 & C4 & 0.319 & D4 & 0.074 \\
\hline A5 & 0.410 & B5 & 0.403 & C5 & 0.176 & D5 & 0 \\
\hline Mean & 0.497 & Mean & 0.293 & Mean & 0.295 & Mean & 0.165 \\
\hline Standard & 0.073 & Standard & 0.160 & Standard & 0.135 & Standard & 0.135 \\
\hline
\end{tabular}


Table 7. Differences between stand types of structure parameters.

\begin{tabular}{|c|c|c|c|c|c|c|}
\hline \multicolumn{7}{|c|}{ About uniform angle index } \\
\hline Df & Sum Df & Sum Sq & Mean Sq & $\mathrm{F}$ value & $\operatorname{Pr}(>F)$ & \\
\hline Dominance & 1 & 0.010 & 0.010 & 4.015 & 0.065 & . \\
\hline Mingling & 1 & 0.001 & 0.001 & 0.549 & 0.471 & \\
\hline Stand type & 3 & 0.004 & 0.001 & 0.516 & 0.678 & \\
\hline Residuals & 14 & 0.036 & 0.003 & & & \\
\hline \multicolumn{7}{|c|}{ About dominance } \\
\hline Df & Sum Df & Sum Sq & Mean Sq & F value & $\operatorname{Pr}(>F)$ & \\
\hline $\begin{array}{l}\text { Uniform angle } \\
\text { index }\end{array}$ & 1 & 0.004 & 0.004 & 5.920 & 0.029 & $*$ \\
\hline Mingling & 1 & 0.000 & 0.000 & 0.578 & 0.460 & \\
\hline Stand type & 3 & 0.006 & 0.002 & 3.053 & 0.064 & . \\
\hline Residuals & 14 & 0.010 & 0.001 & & & \\
\hline \multicolumn{7}{|c|}{ About Mingling } \\
\hline Df & Sum Df & Sum Sq & Mean Sq & F value & $\operatorname{Pr}(>F)$ & \\
\hline Dominance & 1 & 0.010 & 0.010 & 0.471 & 0.504 & \\
\hline $\begin{array}{l}\text { Uniform angle } \\
\text { index }\end{array}$ & 1 & 0.015 & 0.015 & 0.684 & 0.422 & \\
\hline Stand type & 3 & 0.290 & 0.097 & 4.467 & 0.021 & $*$ \\
\hline Residuals & 14 & 0.303 & 0.022 & & & \\
\hline
\end{tabular}

(mixed forest), all plots exhibited a uniform angle index greater than 0.517 , indicating that they were clustered, which is not ideal, because a random distribution is preferred for a productive forest [44]. A clustered distribution is not conducive to the growth of trees in forests because the distribution of forest trees is too dense. When trees display a certain distribution, the competition within the forest is intensified, and this hinders the development of stands. Overall, the average mingling of birch forest is the lowest, which indicates that the composition of birch forest in this area is relatively simple and that there is a greater possibility for birch to grow and prosper.

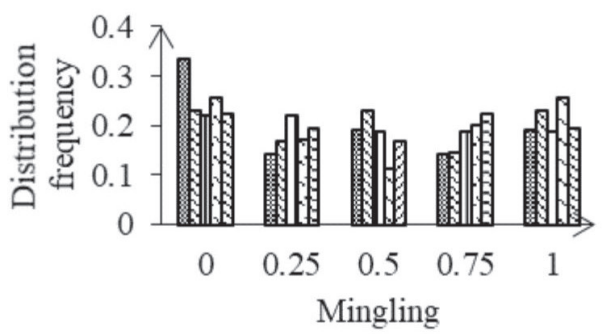

용 $\mathrm{A} 1$

QA2

由 A3

Q A 4

A5

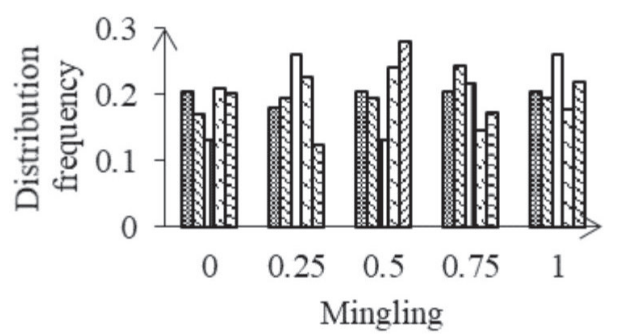

앴 B1

因2

凹 B3

घB4

B5
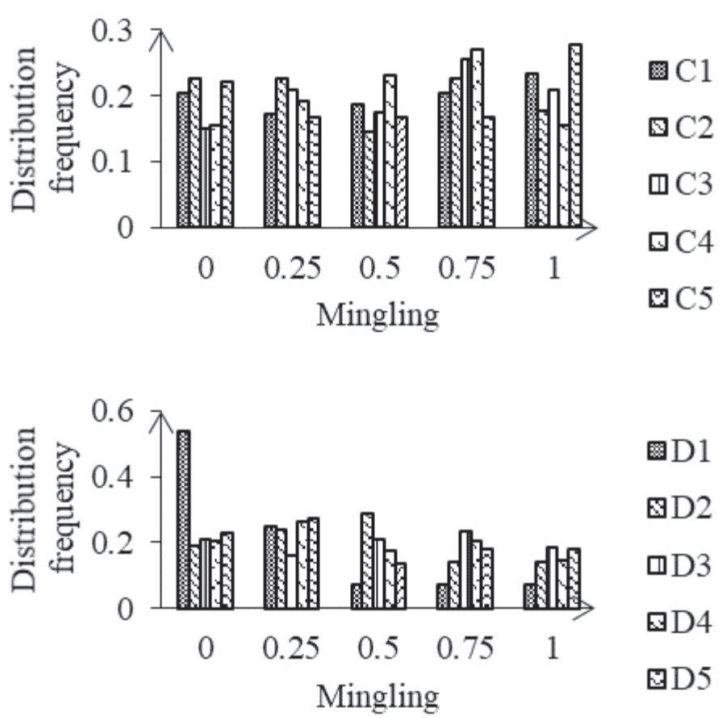

Fig. 6. Distribution frequency of mingling in stands of different types of forests. 


\section{Comparison of Characteristics Among Mixed and Pure Forests}

Because of the inter-relationship between the uniform angle index, dominance and mingling, it is necessary to exclude the influence of other parameters in order to analyze differences in the spatial parameters among the four forest stands. In this paper, one-way analysis of covariance was used to test the similarities and differences in the spatial parameters between mixed and pure forests. As shown in Table 7, there are no significant differences in the uniform angle index between mixed forest and pure forests. Small differences are caused by differences in dominance among the forest types. There is a difference in dominance among the four types of natural forests $(p<0.1)$. Additionally, there is a significant difference in mingling among the four types of natural forests $(p<0.05)$, and a significant different in mean mingling between stand $\mathrm{A}$ and stand $\mathrm{D}$ according to Tukey's test.
Mixed forest showed a significant advantage in mingling, which reached 0.4 or higher, which was higher than the other three forests. Ideally, other types of stands such as pure forests should be chosen as part of the experimental design, but this is almost impossible to achieve in actual natural forests, as shown by the experimental results. Among the five plots within each forest type, the degree of mingling showed high variation, which indicated that there were significant differences in the dominant tree species composition. When the level was set at $p=0.05$, there were no significant differences in the uniform angle index or dominance among the four forest types.

\section{Binary Distribution of Spatial Structure}

As shown by the binary distribution of the uniform angle index and dominance (Fig. 7), the four forests have similar distribution patterns, and the relative frequency at $U=0.50$ is the highest, but the distribution
A1

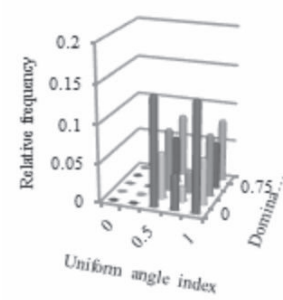

B1

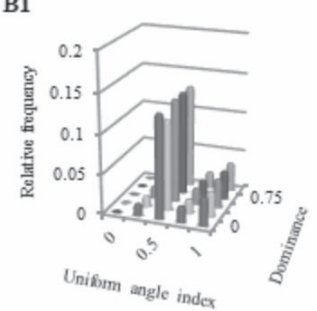

C1

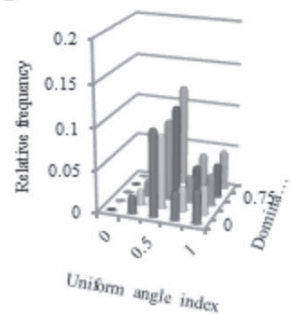

D1

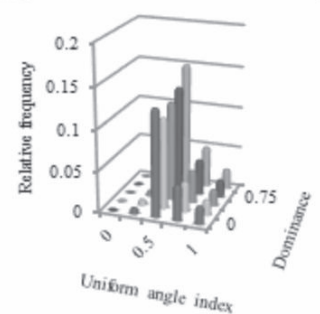

A2

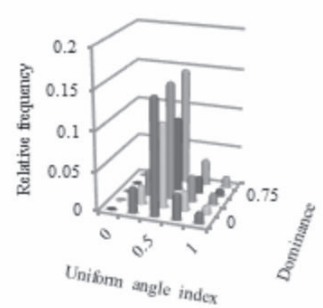

B2

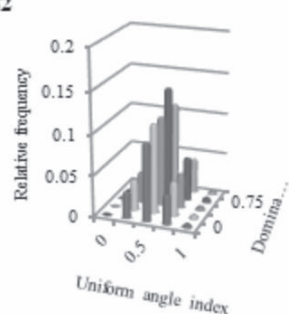

C2

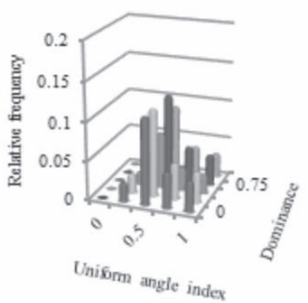

D2

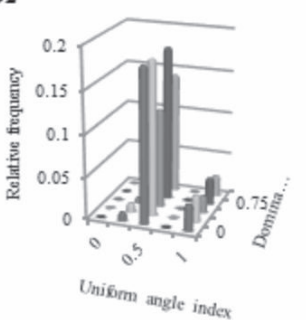

A3

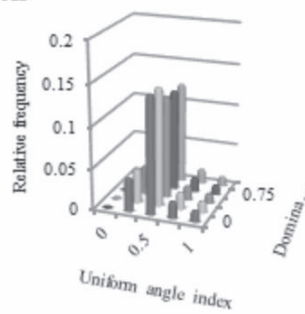

B3

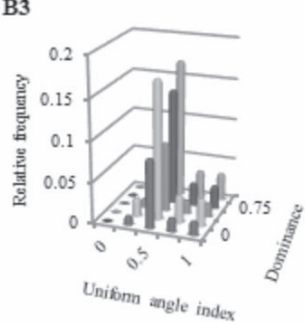

C3

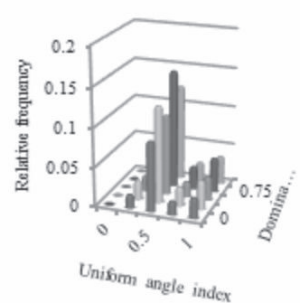

D3

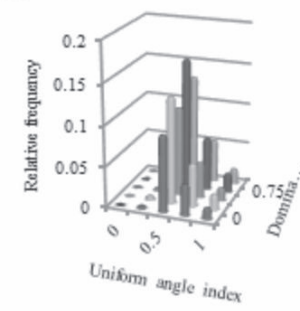

A4

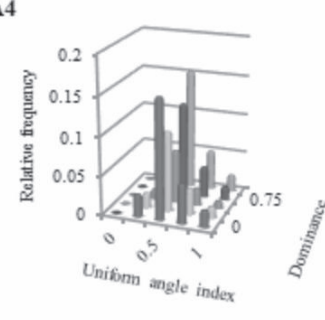

B4

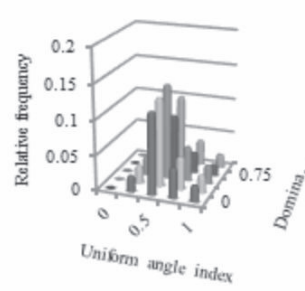

C4

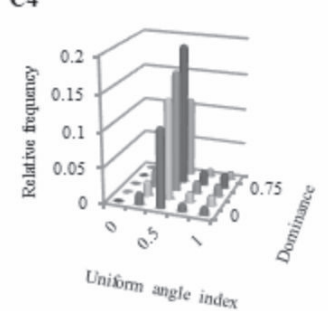

D4

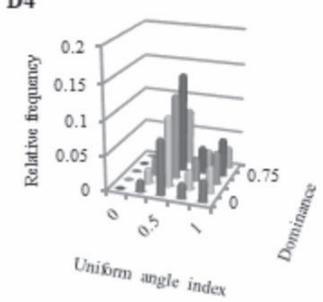

A5

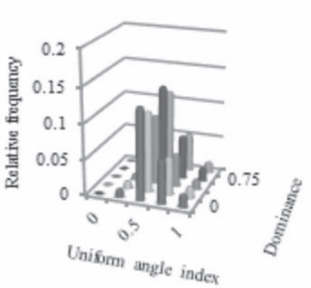

B5

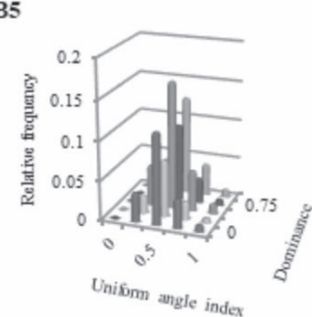

C5

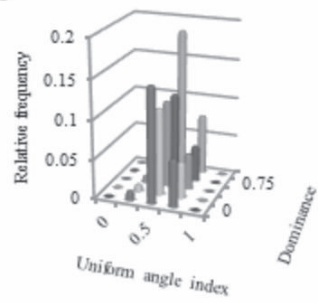

D5

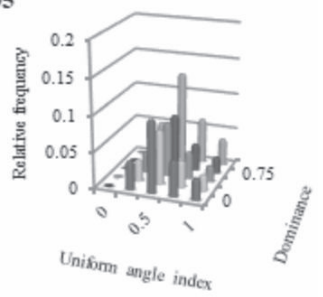

Fig. 7. Binary distributions of the uniform angle index and dominance. 
of dominance has no obvious pattern. The percentages of trees in the five plots in each stand that are randomly distributed and dominant (dominance $=0$ and 0.25 , respectively) are: stand $\mathrm{A}-20.41 \%, 25.56 \%$, $28.71 \%, 25.71 \%$ and $24.31 \%$ with a mean of $24.94 \% \pm 2.68 \%$; stand B - 24.65\%, 20.52\%, 25.52\%, $24.58 \%$ and $18.97 \%$, with a mean of $22.85 \pm 2.60 \%$; stand C $-19.34 \%, 22.58 \%, 21.37 \%, 25.30 \%$ and $25.93 \%$, with a mean of $22.90 \% \pm 2.45 \%$; and stand D $-24.11 \%$, $36.56 \%, 22.63 \%, 18.32 \%$ and $17.68 \%$, with a mean of $23.86 \% \pm 6.81 \%$. We also calculated the percentage of trees that were not randomly distributed or dominant in each forest. The percentages are: stand A - 19.05\%, $13.28 \%, 12.89 \%, 18.29 \%$ and $17.36 \%$, with a mean of $16.17 \pm 2.58 \%$; stand B - $14.73 \%, 19.27 \%, 16.64 \%$, $14.05 \%$ and $16.48 \%$, with a mean of $16.23 \pm 1.82 \%$; stand $\mathrm{C}-21.19 \%, 20.16 \%, 18.93 \%, 11.39 \%$ and $14.81 \%$, with a mean of $17.30 \% \pm 3.66 \%$; and stand D $-15.63 \%$, $7.68 \%, 17.31 \%, 19.91 \%$ and $24.24 \%$, with a mean of $16.95 \% \pm 5.47 \%$.
As shown in Fig. 8, the relationships between uniform angle index and mingling among the four forest stands are random. The percentages of trees that are randomly distributed and highly mixed (mingling $=1.00$ and 0.75 , respectively) are: stand A $-14.29 \%, 32.29 \%, 34.86 \%, 17.14 \%$ and $19.44 \%$, with a mean of $23.61 \% \pm 8.34 \%$; stand B - $27.94 \%$, $13.68 \%, 2.84 \%, 10.93 \%$ and $6.32 \%$, with a mean of $12.34 \pm 8.65 \%$; stand $\mathrm{C}-12.08 \%, 3.23 \%, 2.07 \%$, $28.11 \%$ and $14.81 \%$, with a mean of $12.06 \% \pm 9.41 \%$; and stand D - 15.07\%, 5.22\%, 2.19\%, 20.36\% and $10.10 \%$, with a mean of $10.59 \% \pm 6.56$. Additionally, we calculated the percentages of trees that were not randomly distributed and had a low degree of mixing in each forest. They are: stand A - 19.05\%, $13.28 \%, 7.52 \%, 19.43 \%$ and $19.68 \%$, with a mean of $15.79 \pm 4.77 \%$; stand B - 13.81\%, 24.63\%, 33.27\%, $30.20 \%$ and $36.91 \%$, with a mean of $27.76 \pm 8.06 \%$; stand $\mathrm{C}-31.03 \%, 41.13 \%, 38.33 \%, 11.39 \%$ and $18.52 \%$, with a mean of $28.08 \% \pm 11.44 \%$; and stand D - 22.88\%,
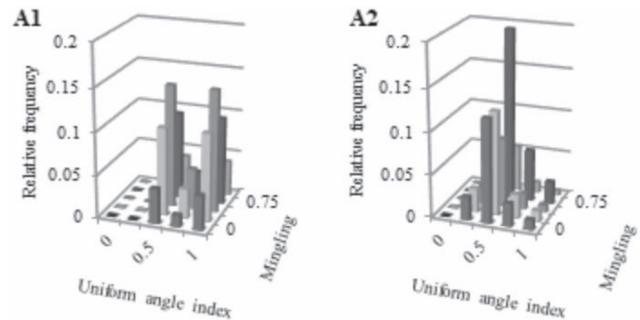

B1

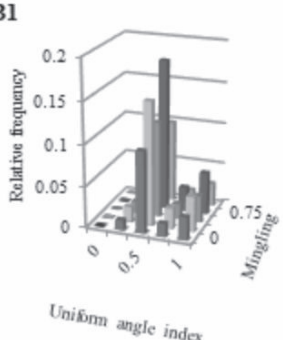

Cl

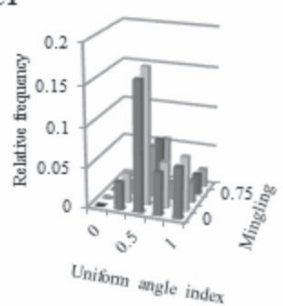

D1

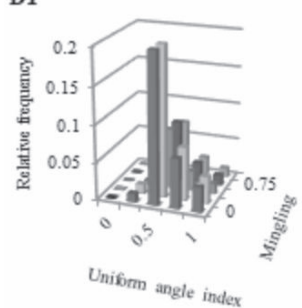

B2

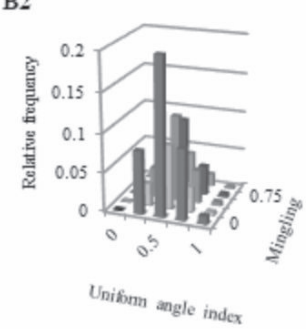

$\mathrm{C2}$

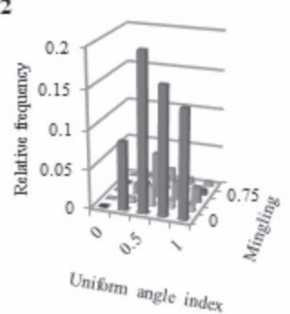

D2

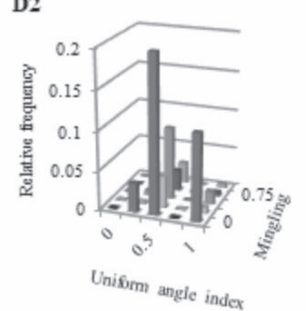

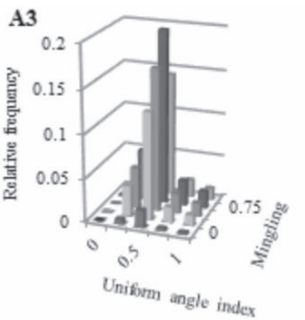

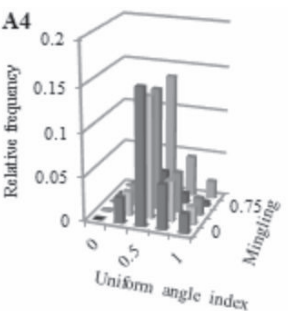

B3

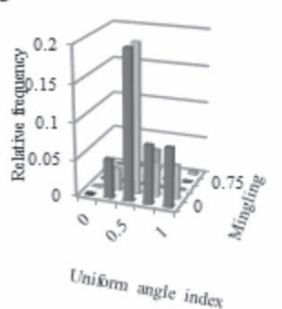

$\mathrm{C} 3$

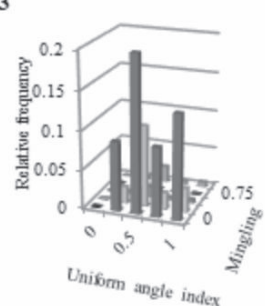

B4

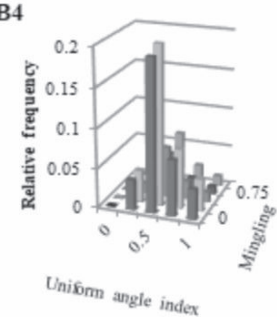

C4

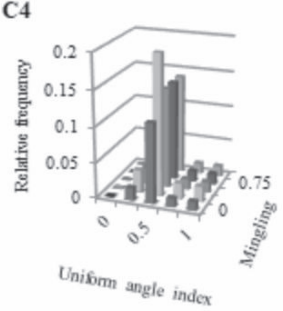

D3

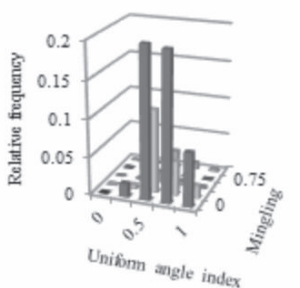

D4

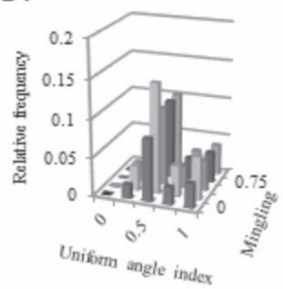

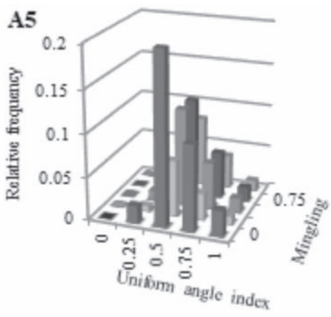

B5

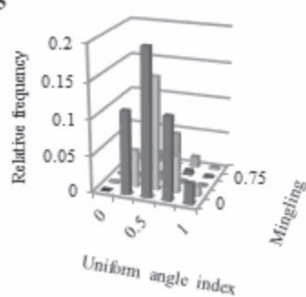

C5

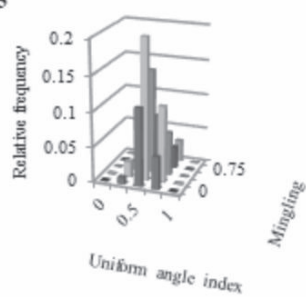

D5

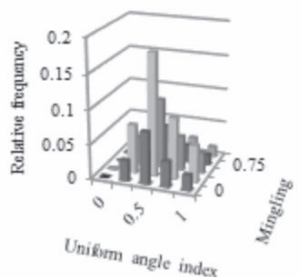

Fig. 8. Binary distributions of the uniform angle index and mingling. 
Al

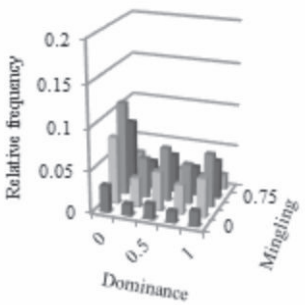

B1

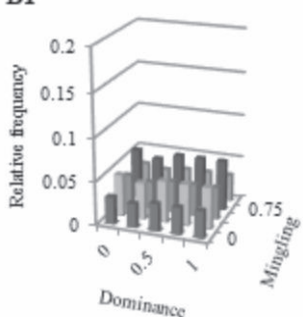

$\mathrm{Cl}$

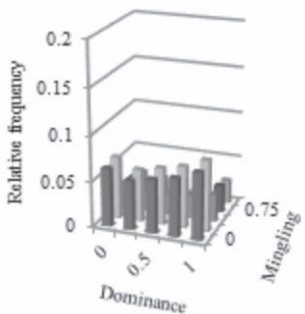

D1

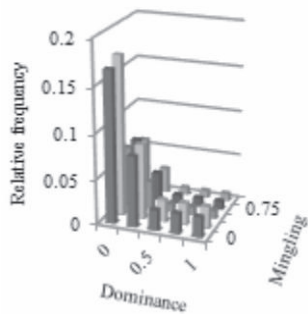

A2

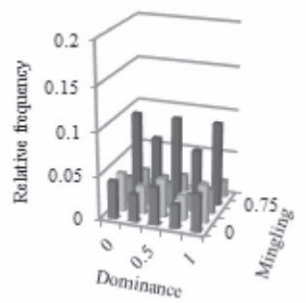

B2

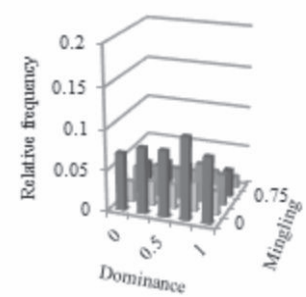

C2

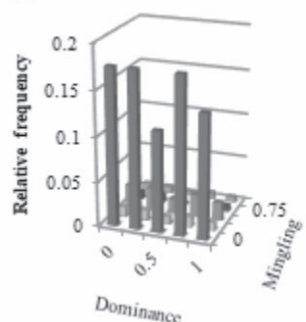

D2

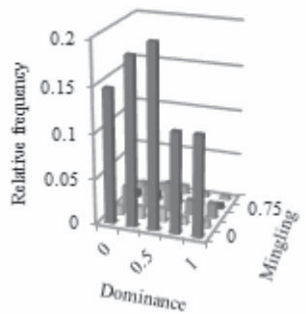

A3

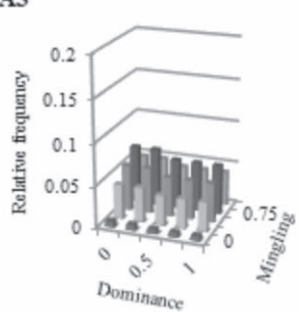

A4

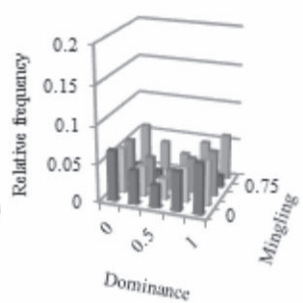

B4

B3
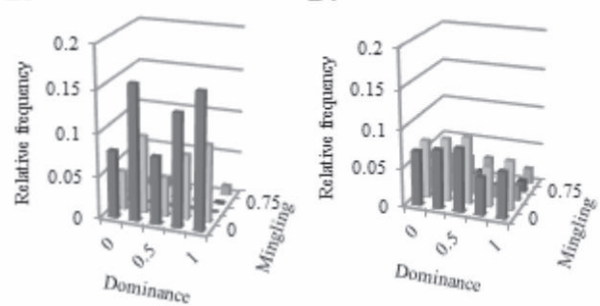

C3

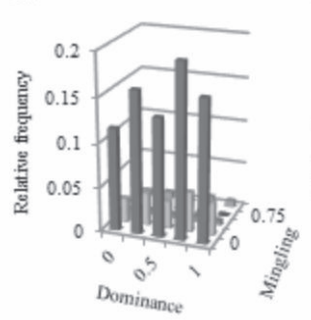

C4

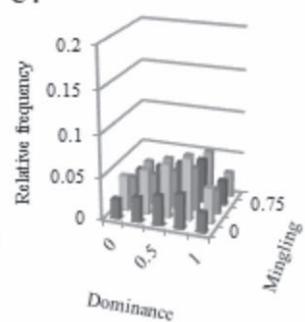

D3

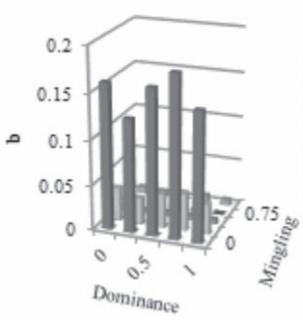

D4

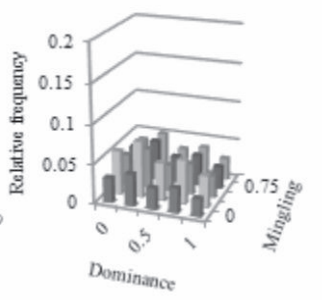

A5

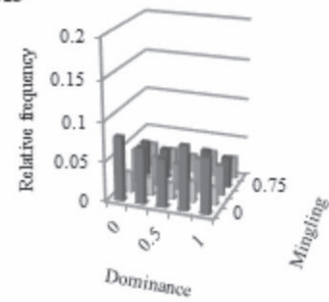

B5

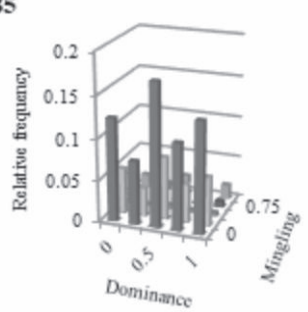

C5

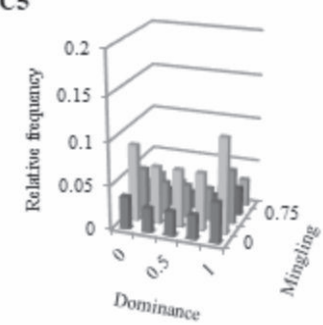

D5

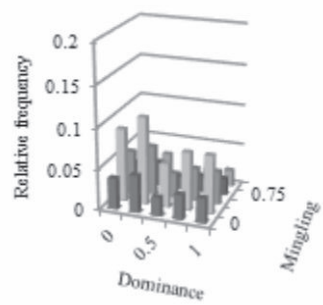

Fig. 9. Binary distributions of the dominance and mingling.

$15.67 \%, 35.05 \%, 19.91 \%$ and $30.30 \%$, with a mean of $24.76 \% \pm 7.02 \%$.

As shown in Fig. 9, the percentages of trees that are highly mixed (mingling $=1.00$ and 0.75 ) and dominant (dominance $=0$ and 0.25 ) are: stand $\mathrm{A}-15.87 \%$, $19.79 \%, 23.24 \%, 12.24 \%$ and $13.89 \%$, with a mean of $17.01 \% \pm 4.01 \%$; stand B - 16.77\%, 8.92\%, 1.70\%, 8.43\% and $3.59 \%$, with a mean of $7.88 \pm 5.23 \%$; stand $\mathrm{C}-$ $8.79 \%, 2.91 \%, 1.26 \%, 13.31 \%$ and $8.64 \%$, with a mean of $6.98 \% \pm 4.37 \%$; and stand D - 18.42\%, 2.76\%, 1.30\%, $18.10 \%$ and $11.11 \%$, with a mean of $10.34 \% \pm 7.28 \%$. Finally, we calculated the percentage of trees that had a low degree of mixing and were dominant in each forest: stand A - 11.11\%, 14.06\%, 8.20\%, 22.20\% and $19.68 \%$, with a mean of $15.05 \pm 5.21 \%$; stand B $-15.78 \%$, $24.63 \%, 45.75 \%, 22.37 \%$ and $34.18 \%$, with a mean of $28.54 \pm 10.43 \%$; stand C - 28.03\%, 33.17\%, 43.81\%, $17.90 \%$ and $24.69 \%$, with a mean of $29.52 \% \pm 8.70 \%$; and stand D - 9.15\%, 23.50\%, 39.43\%, 14.93\% and 20.20\%, with a mean of $21.44 \% \pm 10.22 \%$.

No regular patterns were observed for the binary distribution of spatial structure. However, comparing uniform angle index, mingling and dominance, we find that the relationship between the uniform angle index and dominance differs little among these four stands. In regard to the relationships between the uniform angle index and mingling and between mingling and dominance, the differences among the five plots and among the four stands are significant. This finding confirms that mingling is the most important factor distinguishing these four forest stands.

Unlike the previous studies [1-4], we did not find an obvious superiority in non-spatial structure or spatial structure of mixed forests compared with pure forests. One reason is that secondary forests such as those used in our study contain timber with low quality and low 
economic value - especially in our study where the tree sizes are small. This will increase the time it takes for the mixed forest to achieve its superiority. Second, although other characteristics including tree size and spatial structure are almost all similar, it might be that the superiority of a mixed forest is due to the species diversity itself. If so, then the mingling, in other words, species diversity, is the origin of ecological differences between mixed and pure forests. To test this hypothesis, it would be useful to conduct additional research to test the ecological status in the forest (i.e., soil properties, water capacity, carbon storage, etc.).

\section{Conclusions}

Based on an analysis of the current tree size distribution and stand spatial structure of mixed and pure forest stands in the Greater Khingan Mountains, it is evident that there are cases where - although tree diameters are small and large diameter trees are relatively few in number - the distribution of vegetation is dense and there is little room for growth. There is therefore much competition between trees and the resultant forest is of low quality. Under these conditions a mixed forest does not exhibit an advantage in either tree size or spatial structure characteristics except for mingling. Consequently, the structure status of these secondary forests in the Greater Khingan Mountains is still poor due to the previous cutting and wildfires. This means that completely transforming the stand structure through natural renewal would be a long process. Artificial intervention in the secondary forest may help to reach a stable state more quickly.

\section{Acknowledgements}

This research was funded by the National Key R\&D Program of China (2017YFC0504103) and the Fundamental Research Funds for the Central Universities (2572017AB20).

\section{Conflicts of Interest}

The authors declare no conflicts of interest.

\section{References}

1. AUBERT M., MARGERIE P., ERNOULT A., DECAËNS T., BUREAU F. Variability and heterogeneity of humus forms at stand level: Comparison between pure beech and mixed beech-hornbeam forest. Ann. For. Sci. 63 (2), 177, 2006.

2. SCHUME H., JOST G., HAGER H. Soil water depletion and recharge patterns in mixed and pure forest stands of European beech and Norway spruce. J. Hydrol. 289 (1-4), $258,2004$.
3. GOSSELIN M., FOURCIN D., DUMAS Y., GOSSELIN F., KORBOULEWSKY N., TOÏGO M., VALLET P. Influence of forest tree species composition on bryophytic diversity in mixed and pure pine (Pinus sylvestris L.) and oak (Quercus petraea (Matt.) Liebl.) stands. For. Ecol. Manage. 406, 318, 2017.

4. TORO MANRÍQUEZ M., MESTRE L., LENCINAS M. V., PROMIS Á., MARTÍNEZ PASTUR G., SOLER R. Flowering and seeding patterns in pure and mixed Nothofagus forests in Southern Patagonia. Ecol. Process. 5 (1), 21, 2016.

5. YAN Q., GANG Q., ZHU J., SUN Y. Variation in survival and growth strategies for seedlings of broadleaved tree species in response to thinning of larch plantations: Implication for converting pure larch plantations into larch-broadleaved mixed forests. Environ. Exp. Bot. 129, 108, 2016.

6. YE Y., FANG X. Land use change in Northeast China in the twentieth century: a note on sources, methods and patterns. J. Hist. Geogr. 35 (2), 311, 2009.

7. KOHYAMA T., AIBA S. Dynamics of primary and secondary warm-temperate rain forests in Yakushima Island. Tropics. 6, 383, 1997.

8. ZHANG T., DONG X., GUAN H., MENG Y., RUAN J., WANG Z. Effect of thinning on the spatial structure of a Larix gmelinii Rupr. Secondary forest in the Greater Khingan Mountains. Forests. 9 (11), 720, 2018.

9. CETIN M. The effect of urban planning on urban formations determining bioclimatic comfort area's effect using satellitia imagines on air quality: a case study of Bursa city. Air Qual. Atmos. Heal. 12 (10), 1237, 2019.

10. KAYA E., AGCA M., ADIGUZEL F., CETIN M. Spatial data analysis with R programming for environment. Hum. Ecol. risk Assess. An Int. J. 25 (6), 1521, 2019.

11. CETIN M. Using GIS analysis to assess urban green space in terms of accessibility: Case study in Kutahya. Int. J. Sustain. Dev. World Ecol. 22 (5), 420, 2015.

12. BURGER J.A. Management effects on growth production and sustainability of managed forest ecosystems: Past trends and future directions. For. Ecol. Manage. 258 (10), 2335, 2009.

13. CETIN M., ZEREN I., SEVIK H., CAKIR C., AKPINAR H., A study on the determination of the natural park's sustainable tourism potential. Environ. Monit. Assess. 190 (3), 167, 2018.

14. CETIN M. Evaluation of the sustainable tourism potential of a protected area for landscape planning: A case study of the ancient city of Pompeipolis in Kastamonu. Int. J. Sustain. Dev. World Ecol. 22 (6), 490, 2015.

15. SONG Q., DONG X., LI Z. Effects of Different Transformation Measures on Biodiversity of Three Types of Low-Quality Forest Stands in Great Xing' an Mountains. J. Northeast For. Univ. 40 (4), 85, 2012.

16. ALESSANDRINI A., BIONDI F. DI FILIPPO A., ZIACO E., PIOVESAN G. Tree size distribution at increasing spatial scales converges to the rotated sigmoid curve in two old-growth beech stands of the Italian Apennines. For. Ecol. Manage. 262 (11), 1950, 2011.

17. ANFODILlO T., CARRER M., SIMINI F., POPA I., BANAVAR J. R., MARITAN A. An allometry-based approach for understanding forest structure predicting treesize distribution and assessing the degree of disturbance. Proc. R. Soc. B Biol. Sci. 280 (1751), $20122375,2013$.

18. FOSTER J.R., REINERS W.A. Size distribution and expansion of canopy gaps in a northern Appalachian spruce-fir forest. Vegetatio. 68 (2), 109, 1986. 
19. NABESHIMA E., KUBO T., HIURA T. Variation in tree diameter growth in response to the weather conditions and tree size in deciduous broad-leaved trees. For. Ecol. Manage. 259 (6), 1055, 2010.

20. PRETZSCH H., SCHÜTZE G. Effect of Tree Species Mixing on the Size Structure Density and Yield of Forest Stands. European Journal of Forest Research. 135 (1), 1, 2016.

21. TEMESGEN H., ZHANG C.H., ZHAO X.H. Modelling tree height-diameter relationships in multi-species and multi-layered forests: A large observational study from Northeast China. For. Ecol. Manage. 316, 78, 2014.

22. HÄBEL H., KURONEN M., HENTTONEN H.M., KANGAS A., MYLLYMÄKI M. The effect of spatial structure of forests on the precision and costs of plot-level forest resource estimation. For. Ecosyst. 6 (1), 8, 2019.

23. RODRÍGUEZ-GONZÁLEZ P.M., GARCÍA C., ALBUQUERQUE A., MONTEIRO-HENRIQUES T., FARIA C., GUIMARÃES J. B., MENDONÇA D., SIMÕES F., FERREIRA M. T., MENDES A., MATOS J., ALMEIDA M. H. A spatial stream-network approach assists in managing the remnant genetic diversity of riparian forests. Sci. Rep. 9 (1), 6741, 2019.

24. VERKERK P.J., FITZGERALD J. B., DATTA P., DEES M., HENGEVELD G. M., LINDNER M., ZUDIN S. Spatial distribution of the potential forest biomass availability in Europe. For. Ecosyst. 6 (1), 5, 2019.

25. BI H., FOX J.C., LI Y., LEI Y., PANG Y. Evaluation of Nonlinear Equations for Predicting Diameter from Tree Height. Canadian Journal of Forest Research. 42 (4), 789, 2012.

26. DICKINSON Y.L., BATTAGLIA M.A., ASHERIN L.A. Evaluation of the FVS-CR diameter growth model in structurally-heterogeneous ponderosa pine (Pinus ponderosa Douglas ex C. Lawson) stands in the Southern Rockies and potential modifications. For. Ecol. Manage. 448, 1, 2019.

27. FALKOWSKI M.J., SMITH A.M.S., HUDAK A.T., GESSLER P.E., VIERLING L.A., CROOKSTON N.L. Automated estimation of individual conifer tree height and crown diameter via two-dimensional spatial wavelet analysis of lidar data. Can. J. Remote Sens. 32 (2), 153, 2006

28. FULTON M.R. Patterns in height-diameter relationships for selected tree spicies and sites in eastern Texas. Can. J. For. Res. 29 (9), 1445, 1999.

29. IGE P.O., AKINYEMI G.O., SMITH A.S. Nonlinear growth functions for modeling tree height-diameter relationships for Gmelina arborea (Roxb.) in south-west Nigeria. Forest Sci. Technol. 9 (1), 20, 2013.

30. KEARSLEY E., MOONEN P.C., HUFKENS K., DOETTERL S., LISINGO J., BOYEMBA BOSELA F., BOECKX P., BEECKMAN H., VERBEECK $H$. Model performance of tree height-diameter relationships in the central Congo Basin. Ann. For. Sci. 74 (1), 7, 2017.

31. LIANG P., WANG X., SUN H., FAN Y., WU Y., LIN X., CHANG J. Forest type and height are important in shaping the altitudinal change of radial growth response to climate change. Sci. Rep. 9 (1), 1336, 2019.

32. LI Y.Q., DENG X.W., HUANG Z.H., XIANG W.H., YAN W.D., LEI P.F., ZHOU X.L., PENG C.H. Development and evaluation of models for the relationship between tree height and diameter at breast height for Chinesefir plantations in subtropical China. PLoS One. 10 (4), e0125118, 2015.
33. LIU G., WANG J., DONG P., CHEN Y., LIU Z. Estimating Individual Tree Height and Diameter at Breast Height (DBH) from Terrestrial Laser Scanning (TLS) Data at Plot Level. Forests. 9 (7), 398, 2018.

34. MOHAMAD R., TEE W.P. Relationship between tree height and diameter at breast height for a 16-year old stand of Hopea kerangasensis in Sarawak. Malaysian For. 72 (2), 261, 2009.

35. NG'ANDWE P., CHUNGU D., YAMBAYAMBA A.M., CHILAMBWE A. Modeling the height-diameter relationship of planted Pinus kesiya in Zambia. For. Ecol. Manage. 447, 1, 2019.

36. ÖZÇELIK R., CAO Q. V., TRINCADO G., GÖÇER N. Predicting tree height from tree diameter and dominant height using mixed-effects and quantile regression models for two species in Turkey. For. Ecol. Manage. 419, 240, 2018.

37. RUPŠYS P., PETRAUSKAS E. The bivariate Gompertz diffusion model for tree diameter and height distribution. For. Sci. 56 (3), 271, 2010.

38. PHALLA T., OTA T., MIZOUE N., KAJISA T., YOSHIDA S., VUTHY M., HENG S. The importance of tree height in estimating individual tree biomass while considering errors in measurements and allometric models. Agrivita. 40 (1), 131, 2017.

39. CLARK P.J., EVANS F.C. Distance to Nearest Neighbor as a Measure of Spatial Relationships in Populations. Ecology. 35 (4), 445, 1954.

40. RIPLEY B.D. Modelling Spatial Patterns. J. R. Stat. Soc. Ser. B. 39 (2), 172, 1977.

41. POMMERENING A., STOYAN D. Reconstructing spatial tree point patterns from nearest neighbour summary statistics measured in small subwindows. Can. J. For. Res. 38 (5), 1110, 2008.

42. SIMPSON E.H., Measurement of Diversity. Nature. 163 (4148), 688, 1949.

43. HUI G. A new parameter for stand spatial structure neighborhood comparison. For. Res. 12, 1, 1999.

44. HUI G., VON GADOW K., ALBERT M. The neighbourhood pattern - a new structural parameter for describing distribution of forest tree position. Sci. Silvae Sin. 35, 37, 1999.

45. AGUIRRE O., HUI G., VON GADOW K., JIMÉNEZ J. An analysis of spatial forest structure using neighbourhood-based variables. For. Ecol. Manage. 183 (1-3), 137, 2003.

46. HUI G.Y., HU Y.B., ZHAO Z.H. Evaluating tree species segregation based on neighborhood spatial relationships. J. Beijing For. Univ. 30, 131, 2008.

47. HU Y., HUI G., QI J., AN H., HAO G. Analysis of the Spatial Structure of Natural Korean Pine Broad Leaved Forest. For. Res. 16 (5), 523, 2003.

48. HORÁK J., MATERNA J., HALDA J.P., MLADENOVIĆ S., BOGUSCH P., PECH P. Biodiversity in remnants of natural mountain forests under conservation-oriented management. Sci. Rep. 9, 89, 2019.

49. DONG L., LIU Z., LI F., JIANG L. Quantitative analysis of forest spatial structure and optimal species composition for the main forest types in Daxing'anling Northeast China. For. Res. 27 (6), 734, 2014.

50. HUI G., POMMERENING A. Analysing tree species and size diversity patterns in multi-species uneven-aged forests of Northern China. For. Ecol. Manage. 316, 125, 2014.

51. WAN P., ZHANG G., WANG H., ZHAO Z., HU Y., ZHANG G., HUI G., LIU W. Impacts of different forest 
management methods on the stand spatial structure of a natural Quercus aliena var. acuteserrata forest in Xiaolongshan China. Ecol. Inform. 50, 86, 2019.

52. WONN H.T., O'HARA K.L. Height:diameter ratios and stability relationships for four northern Rocky Mountain tree species. West. J. Appl. For. 16 (2), 87, 2001.
53. XIANG W., LIU S., LEI X., FRANK S.C., TIAN D., WANG G., DENG X. Secondary forest floristic composition structure and spatial pattern in subtropical China. J. For. Res. 18 (1), 111, 2013. 
